\title{
Molybdenum Cofactor Biosynthesis in Humans Identification of Two Complementation Groups of Cofactor-deficient Patients and Preliminary Characterization of a Diffusible Molybdopterin Precursor
}

Jean L. Johnson, “ Margot M. Wuebbens, * Roseann Mandell, and Vivian E. Shih

${ }^{*}$ Department of Biochemistry, Duke University Medical Center, Durham, North Carolina 27710; and Amino Acid Disorder Laboratory, Massachusetts General Hospital, and Department of Neurology, Harvard Medical School, Boston, Massachusetts 02114

\begin{abstract}
Molybdenum cofactor deficiency is a devastating disease with affected patients displaying the symptoms of a combined deficiency of sulfite oxidase and xanthine dehydrogenase. Because of the extreme lability of the isolated, functional molybdenum cofactor, direct cofactor replacement therapy is not feasible, and a search for stable biosynthetic intermediates was undertaken. From studies of cocultured fibroblasts from affected individuals, two complementation groups were identified. Coculture of group A and group B cells, without heterokaryon formation, led to the appearance of active sulfite oxidase. Use of conditioned media indicated that a relatively stable, diffusible precursor produced by group $B$ cells could be used to repair sulfite oxidase in group $A$ recipient cells. Although the extremely low levels of precursor produced by group B cells preclude its direct characterization, studies with a heterologous, in vitro reconstitution system suggest that the precursor that accumulates in group $B$ cells is the same as a molybdopterin precursor identified in the Neurospora crassa molybdopterin mutant nit-1, and that a converting enzyme is present in group A cells which catalyzes an activation reaction analogous to that of a converting enzyme identified in the Escherichia coli molybdopterin mutant ChlA1.
\end{abstract}

\section{Introduction}

Molybdenum cofactor deficiency was first identified in 1978 (2) and has now been documented in more than 20 patients (3-5). The molybdenum cofactor is a complex of a reduced pterin species termed molybdopterin and molybdenum (Fig. 1). The cofactor is required for the function of at least three enzymes in humans: sulfite oxidase, xanthine dehydrogenase, and aldehyde oxidase. A deficiency of the cofactor results in symptoms of sulfite oxidase deficiency, which include seizures and other neurological abnormalities, mental retardation, and dislocated ocular lenses, in combination with xanthinuria, and most often leads to death at a young age. No symptoms attributable specifically to the absence of aldehyde oxidase have been identified. Molybdenum cofactor deficiency is inherited as an autosomal recessive trait (5) and can be diagnosed pre-

A portion of this work was presented earlier in abstract form (1). Address reprint requests to Dr. Johnson.

Received for publication 27 June 1988 and in revised form 27 September 1988.

J. Clin. Invest.

(C) The American Society for Clinical Investigation, Inc.

0021-9738/89/03/0897/07 \$2.00

Volume 83, March 1989, 897-903 natally by assay of sulfite oxidase activity in cultured amniotic cells (6) or chorionic villus biopsy (7). However, at present there is no cure or effective therapy for molybdenum cofactor deficiency. The cofactor itself is exceedingly unstable, such that its structural characterization could be carried out only by study of stable degradation products $(8,9)$. Thus direct cofactor replacement therapy is not feasible, and an understanding of the biosynthetic pathway and identification of stable precursor molecules which may be intermediates in the pathway become extremely important in development of a strategy to alleviate the symptoms of the deficiency disease.

In the results described below, we show that molybdenum cofactor deficient patients can be assigned to two complementation groups. A relatively stable diffusible molybdopterin precursor which is produced by group B cells and utilized by group A cells to synthesize active molybdenum cofactor is identified, and evidence is presented which suggests that this diffusible intermediate is identical to a molybdopterin precursor that accumulates in a molybdopterin mutant of Neurospora crassa (10). The presence of a converting enzyme activity in group A cells that activates the precursor to yield functional molybdopterin and is analogous to a converting enzyme identified in a molybdopterin mutant of $E$. coli is also documented. From the results of studies described in this article, it is possible to define a pathway outlining the late steps in the biosynthesis of the molybdenum cofactor. That pathway, with the sites that appear to be defective in the two classes of molybdenum cofactor-deficient patients and in the Neurospora and Escherichia coli molybdopterin mutants indicated, is shown in Fig. 2.

\section{Methods}

Assay of sulfite oxidase in cultured fibroblasts. Fibroblasts were obtained and cultured as described previously (11). For assay of sulfite oxidase activity, frozen cell pellets $\left(3-10 \times 10^{6}\right.$ cells) were thawed, suspended in $1 \mathrm{ml} 0.01 \mathrm{M}$ Tris- $\mathrm{HCl}, \mathrm{pH} 8.5$, with $50 \mu \mathrm{l}$ of $1 \%$ sodium deoxycholate, frozen and thawed once, and passed through a 27-gauge needle several times. After the addition of $10 \mu \mathrm{l}$ of $50 \mathrm{mM} \mathrm{NaCN}$, the mixture was centrifuged at $12,000 \mathrm{~g}$ for $5 \mathrm{~min}$. The supernatant fraction was applied to a column of Sephadex G-25 (PD-10, Pharmacia Fine Chemicals, Piscataway, NJ; $9.1 \mathrm{ml}$ bed volume) equilibrated with $0.1 \mathrm{M}$ Tris- $\mathrm{HCl}$, pH 8.5, with $0.1 \mathrm{mM}$ EDTA. The column was washed with $2 \mathrm{ml}$ of the same buffer, and the protein fraction was eluted with $1.5 \mathrm{ml}$ of buffer and assayed for sulfite oxidase activity (11). A unit of sulfite oxidase activity is defined as the amount of enzyme producing an absorbance change at $550 \mathrm{~nm}$ of 0.001 absorbance unit per min at $25^{\circ} \mathrm{C}$.

Each fibroblast cell line described was cultured individually and shown to lack sulfite oxidase activity. Patients were identified as molybdenum cofactor deficient by demonstrated absence of xanthine dehydrogenase activity in combination with sulfite oxidase deficiency and, in most cases, by their failure to excrete urothione, the metabolic 
<smiles>Nc1nc2c(c(=O)[nH]1)NC(/C(S)=C(\S)COCCOC(=O)O)CN2</smiles>

MOLYBDOPTERIN

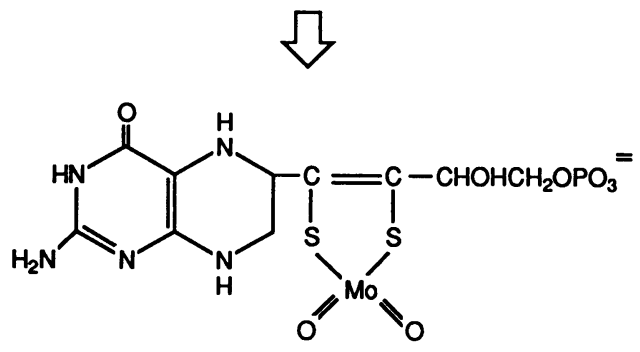

\section{MOLYBDENUM COFACTOR}

Figure 1. Structures of molybdopterin and the molybdenum cofactor. The dioxo structure shown for the molybdenum cofactor is characteristic of the molybdenum center in sulfite oxidase and nitrate reductase. In the molybdenum center of xanthine dehydrogenase, one of the oxo groups is replaced by a terminal sulfide ligand. The oxidation state of the pterin ring may vary in different molybdoenzymes.

degradation product of the molybdenum cofactor (12). For clarity, patients and fibroblast lines are referred to by a code which designates the complementation group to which they have been assigned based on the studies reported here. The corresponding patient initials and references to the case descriptions are as follows: A1, R.M. (11, 13); A2, E.V. (2-4); A3, K.Z. (4, 14), A4, K.M. (4); A5, M.V. (4); A6, F.M. (5); A7, C.K. (5); B1, S.B. (15); B2, Z.B. (15), B3, W.T. Patients B1 and B2 are sibs, and patients $A 2$ and $A 5$ are distantly related. All other patients are unrelated.

Complementation analyses. Complementation experiments were carried out as described previously (16). Aliquots of fibroblasts were mixed in a 1:1 ratio and inoculated into $100-\mathrm{mm}$ culture dishes at a density of $1.2 \times 10^{6}$ cells per dish. Cell fusion was initiated by exposure to $50 \%$ polyethylene glycol 1000 . Fibroblasts were plated $24 \mathrm{~h}$ after fusion, and grown for $11 \mathrm{~d}$ before harvesting. Mixtures of two fibroblast lines (1:1) not exposed to polyethylene glycol were subjected to the same treatments.
Culture and preparation of cell-free extracts of Neurospora and E. coli. Neurospora nit-1 mycelia were grown, induced for nitrate reductase, and harvested as previously described (17). Frozen mycelia were thawed, homogenized in $2 \mathrm{vol}$ of $0.1 \mathrm{M}$ potassium phosphate buffer, pH 7.4, with 5 mM EDTA, $1 \mathrm{mM}$ phenylmethylsulfonyl fluoride, and $1 \mathrm{mM}$ dithiothreitol using a Duall glass grinder (Kontes Co., Vineland, $\mathrm{NJ}$ ) and centrifuged at $15,000 \mathrm{~g}$ for $20 \mathrm{~min}$. The supernatant fraction was used for reconstitution studies. For studies requiring further fractionation of the nit- 1 extract, $2.0 \mathrm{ml}$ of the supernatant was applied to a column of Sephadex G-25 (PD-10, Pharmacia Fine Chemicals) equilibrated with homogenization buffer. The column was washed with $1 \mathrm{ml}$ of buffer and the excluded, high molecular weight fraction was eluted with $2.5 \mathrm{ml}$ of buffer. After another $2.0-\mathrm{ml}$ wash which was discarded, the low molecular weight fraction was eluted in $4 \mathrm{ml}$.

E. coli ChlAl cells (18) were grown on LB medium (Gibco, Grand Island, NY) and harvested at late log or early stationary phase by centrifugation at $5,000 \mathrm{~g}$ for $25 \mathrm{~min}$. Cells were washed once with water and suspended in $5 \mathrm{vol} 0.01 \mathrm{M}$ potassium phosphate, $\mathrm{pH}$ 7.4. Extracts were prepared with a French pressure cell and stored at $-20^{\circ} \mathrm{C}$.

Assay of molybdopterin precursor in conditioned culture media. Reconstitution mixtures containing $40 \mu \mathrm{l}$ of medium, $25 \mu \mathrm{l}$ of ChlAl extract, $25 \mu \mathrm{l}$ of nit-1 high molecular weight fraction, and $10 \mu \mathrm{l}$ of 0.5 $M$ sodium molybdate were incubated at room temperature for $15 \mathrm{~min}$. Reconstituted nitrate reductase activity was assayed by the addition of $0.4 \mathrm{ml}$ of a solution of substrates to yield in the $0.5 \mathrm{ml}$ assay mix: 0.35 mM NADPH, $30 \mathrm{mM} \mathrm{KNO}{ }_{3}, 10 \mu \mathrm{M}$ flavin adenine dinucleotide, 5 $\mathrm{mM} \mathrm{Na} \mathrm{SO}_{3}$, and $0.1 \mathrm{M}$ potassium phosphate, $\mathrm{pH} 7.2$ (19). After incubation for $20 \mathrm{~min}$ at room temperature, nitrite produced was quantitated by a colorimetric assay (17) and monitored at $540 \mathrm{~nm}$. Blank reactions with NADPH omitted were also run and used to correct for any nonspecific contributions to the $540 \mathrm{~nm}$ absorbance.

Assay of converting enzyme in fibroblast extracts. Cells were lysed as described for assay of sulfite oxidase activity. Lysates were used directly with no centrifugation or G-25 chromatography steps. Reconstitution mixtures containing $60 \mu \mathrm{l}$ of fibroblast extract, $30 \mu \mathrm{l}$ of nit-1 extract (complete extract or high molecular weight fraction), and $10 \mu \mathrm{l}$ of $0.5 \mathrm{M}$ sodium molybdate were incubated at $4^{\circ} \mathrm{C}$ overnight and then assayed for nitrate reductase activity as described above. To demonstrate that fibroblast converting enzyme could activate the nit-1 molybdopterin precursor, reconstitution mixtures were prepared as above but with $30 \mu \mathrm{l}$ of the nit-1 low molecular weight fraction. After overnight incubation at $4^{\circ} \mathrm{C}$ to allow activation of the precursor species, 50 $\mu \mathrm{l}$ of the nit- 1 high molecular weight fraction was added as a source of apo nitrate reductase to accept active molybdenum cofactor. The mixture was incubated at room temperature for $15 \mathrm{~min}$ to allow reconstitution and then assayed for nitrate reductase activity.
APO SULFITE OXIDASE (humans)
or

APO NITRATE REDUCTASE (E.colior Neurospora)

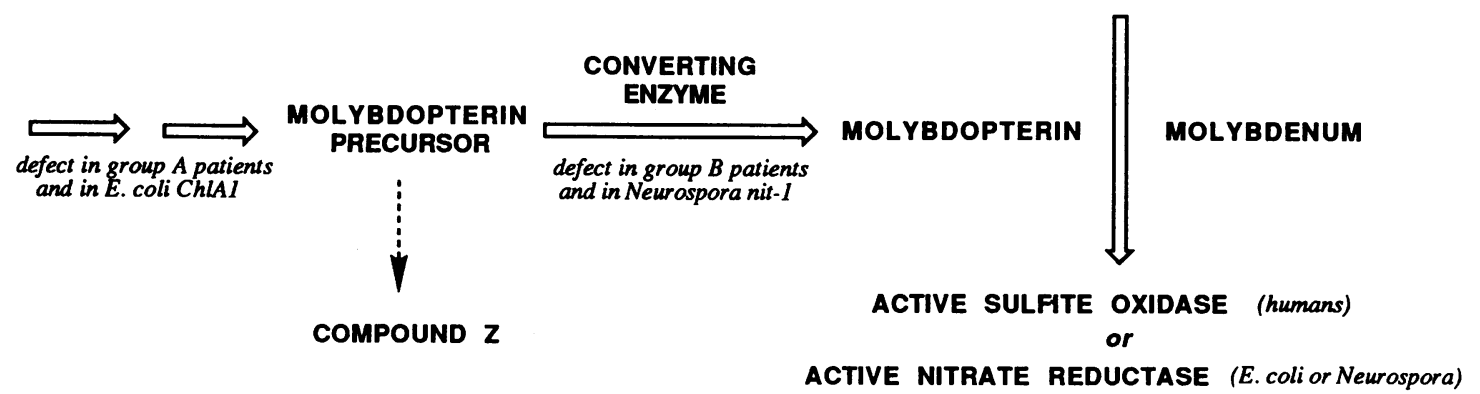

Figure 2. Outline of the late steps in the biosynthesis of the molybdenum cofactor in humans and microorganisms. The defects in group A patients and E. coli ChlAl are at a step preceding converting enzyme in the synthesis of molybdopterin but have not been further localized and may not be the same in each case. Compound $\mathrm{Z}$ is an oxidized degradation product of the molybdopterin precursor. 
Assays for compound Z. Fibroblast extracts prepared as for assay of sulfite oxidase (uncentrifuged) and conditioned culture medium samples were acidified to $\mathrm{pH} 1$ with $\mathrm{HCl}$ and a solution of $1 \% \mathrm{I}_{2}$ with $2 \% \mathrm{KI}$ was added in sufficient excess to maintain a yellow color. After $30 \mathrm{~min}$ oxidation, samples were centrifuged at $12,000 \mathrm{~g}$ for $5 \mathrm{~min}$ and chromatographed in $50 \mathrm{mM}$ ammonium acetate, $\mathrm{pH} 5$, on a C-18 HPLC column $(4.6 \times 250 \mathrm{~mm}, 10 \mu$, Altech Associates, Deerfield, IL) using a Hewlett-Packard 1090 liquid chromatograph with an HP 1040 A diode-array detector and an HP 1046 A fluorescence detector (Hewlett-Packard Co., Palo Alto, CA). Under these conditions authentic compound $Z(10)$ elutes at $6 \mathrm{~min}$. Samples of urine $(10 \mathrm{ml})$ were acidified to $\mathrm{pH} 3$ with $\mathrm{HCl}$, incubated for $30 \mathrm{~min}$ with $\mathrm{I}_{2} / \mathrm{KI}$, centrifuged to clarify, and applied to a $0.8 \mathrm{ml}$ column of Florisil resin (Fisher Scientific Co., Springfield, NJ) equilibrated with $0.01 \mathrm{~N} \mathrm{HCl}$. The column was washed with $10 \mathrm{ml}$ of $0.01 \mathrm{~N} \mathrm{HCl}$, and the material of interest was eluted with $5 \mathrm{ml} 50 \%$ acetone in water. The eluant was adjusted to $\mathrm{pH} 8$ with $\mathrm{NaOH}$ and applied to a $1.0 \mathrm{ml}$ column of QAE Sephadex (acetate form) equilibrated with $\mathrm{H}_{2} \mathrm{O}$. The column was washed with $3 \mathrm{ml}$ of $\mathrm{H}_{2} \mathrm{O}$ followed by $10 \mathrm{ml} 0.01 \mathrm{M}$ acetic acid and the material of interest was eluted with $0.01 \mathrm{M} \mathrm{HCl}$. Fractions of $3 \mathrm{ml}$ were collected and analyzed for the presence of compound Z by HPLC in 50 $\mathrm{mM}$ ammonium acetate, as described above, and also with $5 \%$ methanol acidified to $\mathrm{pH} 2$ with $\mathrm{HCl}$ as mobile phase. Authentic compound Z, purified from E. coli ChlM cells (10) was carried through the same Florisil and QAE chromatography steps; it was eluted from a $1 \mathrm{ml}$ column of QAE Sephadex with $0.01 \mathrm{~N} \mathrm{HCl}$ in fractions 10 and 11 .

Active molybdopterin precursor in urine samples was assayed as described for assay in conditioned cell culture medium.

\section{Results}

Reconstitution of sulfite oxidase in cultured fibroblasts. Fibroblasts cultured from patients with molybdenum cofactor deficiency contain no active sulfite oxidase assayable by a sensitive spectrophotometric assay. However, as shown in Table I, cultures containing heterokaryons produced by polyethylene glycol fusion of cells from patient B1 or sib B2 with those from patient A1 gave positive results when assayed for sulfite oxidase. Also positive were cultures containing Al cells grown in the presence of B1 or B2 cells but with no induction of heterokaryon formation. Coculture without cell fusion has been extended to include combinations of fibroblasts from a large number of molybdenum cofactor-deficient patients and the results are summarized in Table II. Initially it was found that all crosses that contained cells from B1 or B2 showed reconstitution of sulfite oxidase activity while crosses between any of the other patients gave negative results. These results define two complementation groups: group A consisting of seven patients (A1-A7) and group B consisting of B1 and B2. Recently, another unrelated molybdenum cofactor-deficient patient has been assigned to group B. As shown in Table II, cells from patient $\mathrm{B} 3$ complement $\mathrm{A} 6$ and $\mathrm{A} 7$ but yield no activity when cultured with cells from B1.

The presence of sulfite oxidase activity in cocultured fibroblasts in the absence of heterokaryon formation suggests that complementation is occurring by means of a diffusible molecule produced and excreted into the culture medium by one cell class which is then taken up and processed to produce active molybdenum cofactor by cells of the other classification group. To establish that such is the case, to determine which complementation group produces and which uses the putative precursor species, and to gain some insight into the stability of such a precursor species, experiments were undertaken culturing recipient cells in medium which had been conditioned by
Table I. Sulfite Oxidase Activity in Fibroblast Heterokaryons Induced by Polyethylene Glycol Fusion

\begin{tabular}{ccc}
\hline Cross & Sulfite oxidase & Polyethylene glycol \\
\hline & U/mg soluble protein & \\
A1 $\times$ B1 & 5.1 & + \\
& 7.2 & - \\
A1 $\times$ B2 & 10.1 & + \\
& 6.7 & - \\
B1 $\times$ B2 & $<0.8$ & + \\
& $<0.8$ & - \\
B1 $\times$ control & 6.2 & + \\
& 7.4 & - \\
B2 $\times$ control & 9.3 & + \\
& 8.8 & - \\
A3 $\times$ A4 & $<0.8$ & - \\
& $<0.8$ & + \\
\hline
\end{tabular}

For each cross, fibroblasts were combined in a 1:1 ratio. Cells were incubated with $(+)$ or without $(-)$ polyethylene glycol for $24 \mathrm{~h}$, plated and cultured for $11 \mathrm{~d}$, harvested, and assayed for sulfite oxidase activity.

prior culture of cells of a donor line. The results of one experiment, shown in Table III, confirm that cells from patient B1 produce a transferable species and demonstrate that it is of sufficient stability to be utilized by A3 cells even after B 1 cells have been removed from the culture. These results indicate that group B cells are the precursor donors and group A cells are the acceptor cells which convert the precursor to active

Table II. Sulfite Oxidase Activity in Mixed Fibroblast Cultures from Molybdenum Cofactor-deficient Patients

\begin{tabular}{|c|c|c|c|c|c|}
\hline \multicolumn{2}{|c|}{ Group $\mathbf{A} \times$ group $\mathbf{A}$} & \multicolumn{2}{|c|}{ Group A $\times$ group B } & \multicolumn{2}{|c|}{ Group B $\times$ group B } \\
\hline Cell lines & $\begin{array}{c}\text { Sulfite } \\
\text { oxidase }\end{array}$ & Cell lines & $\begin{array}{c}\text { Sulfite } \\
\text { oxidase }\end{array}$ & Cell lines & $\begin{array}{c}\text { Sulfite } \\
\text { oxidase }\end{array}$ \\
\hline \multicolumn{6}{|c|}{$U / m g$ soluble protein } \\
\hline $\mathrm{A} 1 \times \mathrm{A} 2$ & $-*$ & $\mathbf{A} 1 \times B_{1}$ & 5.0 & B1 $\times$ B3 & - \\
\hline $\mathbf{A} 1 \times \mathbf{A} 3$ & - & $\mathrm{A} 2 \times \mathrm{B} 1$ & 9.6 & & \\
\hline $\mathrm{A} 1 \times \mathrm{A} 4$ & - & $\mathrm{A} 3 \times \mathrm{B} 1$ & 3.8 & & \\
\hline $\mathrm{A} 1 \times \mathrm{A} 5$ & - & $\mathrm{A} 4 \times \mathrm{B} 1$ & 7.2 & & \\
\hline $\mathrm{A} 1 \times \mathrm{A} 6$ & - & $\mathrm{A} 5 \times \mathrm{B} 1$ & 1.7 & & \\
\hline $\mathbf{A} 1 \times \mathbf{A} 7$ & - & $\mathrm{A} 6 \times \mathrm{B} 1$ & 4.0 & & \\
\hline $\mathrm{A} 2 \times \mathbf{A} 3$ & - & $\mathbf{A} 7 \times \mathbf{B} 1$ & 4.7 & & \\
\hline $\mathrm{A} 2 \times \mathrm{A} 4$ & - & $\mathrm{A} 6 \times \mathrm{B} 3$ & 1.5 & & \\
\hline $\mathrm{A} 2 \times \mathrm{A} 5$ & - & $\mathrm{A} 7 \times \mathrm{B} 3$ & 1.6 & & \\
\hline A3 $\times$ A4 & - & & & & \\
\hline $\mathrm{A} 3 \times \mathrm{A} 5$ & - & & & & \\
\hline $\mathrm{A} 4 \times \mathrm{A} 5$ & - & & & & \\
\hline $\mathrm{A} 6 \times \mathrm{A} 7$ & - & & & & \\
\hline
\end{tabular}

For each cross, fibroblasts from two molybdenum cofactor-deficient patients were combined and cultured for periods ranging 3-13 d, harvested, and assayed for sulfite oxidase activity. The values given for $A 1 \times B 1$ and $A 3 \times B 1$ are averages of values obtained from four and three replicate experiments, respectively.

* Dash indicates no activity detected $(<0.5)$. 
Table III. Sulfite Oxidase Activity in Fibroblasts Cultured in Conditioned Media

\begin{tabular}{ccc}
\hline Donor cell line & Recipient cell line & Sulfite oxidase activity \\
\hline & & U/mg soluble protein \\
A2 & A4 & $-*$ \\
A3 & B1 & - \\
B1 & A3 & 1.8
\end{tabular}

Donor fibroblasts were cultured for $3 \mathrm{~d}$ under standard conditions; the culture medium was then collected and centrifuged. A mixture of conditioned medium $(70 \%)$ and fresh medium $(30 \%)$ was used for plating recipient cells. Dishes were fed every $2 \mathrm{~d}$ with a mixture of conditioned medium and fresh medium, harvested on day 10 , and assayed for sulfite oxidase activity.

* Dash indicates no activity detected $(<0.5)$.

molybdopterin. It would appear as well that the genetic defect in group $\mathrm{A}$ lies in an enzyme that precedes the enzyme which is defective in group $B$ in the molybdopterin biosynthetic pathway.

Characterization of the molybdopterin precursor produced by group $B$ patients. Because of the exceedingly low levels of molybdoenzymes, molybdopterin, and its precursors which are present in cultured fibroblasts, it was clear that purification of the diffusible intermediate from group B cells or conditioned medium would be a difficult task, further hampered by the lengthy assay procedure relying on reconstitution of sulfite oxidase activity in cultured group A cells. To overcome these problems and facilitate a partial characterization of the precursor produced by group B patients, we turned to a heterologous in vitro reconstitution system which is described below:

The most widely used assay for active molybdenum cofactor utilizes the nit-1 mutant of Neurospora crassa, which is defective in molybdopterin biosynthesis. The nit-1 strain accumulates a soluble, inactive apo nitrate reductase which can be readily reconstituted in vitro by a source of active molybdenum cofactor. The reconstitution takes place rapidly at room temperature or somewhat more slowly at $4^{\circ} \mathrm{C}$ requiring only a crude extract of nit-1 mycelia, a source of molybdenum cofactor or molybdopterin and inorganic molybdate. After reconstitution, the active nitrate reductase is incubated with substrates and nitrite produced is quantitated by a colorimetric procedure.

One precaution must be taken when utilizing the nit-1 system as an assay for active molybdopterin. While the nit-1 mutant contains no functional molybdopterin, it does accumulate a low molecular weight precursor of molybdopterin (10). In the presence of an appropriate converting enzyme, added exogenously to the nit-1 extracts, this precursor can be activated to molybdopterin which in turn will reconstitute the apo nitrate reductase. The converting enzyme which activates the nit-1 precursor was first identified (10) in a mutant of $E$. coli, $C h l A 1$, which also is defective in molybdopterin synthesis. Specifically, it was observed that incubation of an extract of ChlAl cells with an unfractionated extract of nit-l led to the appearance of active nitrate reductase. Separation of the low molecular weight fractions of the nit- 1 by gel exclusion chromatography produced a preparation of apo nitrate reductase (high molecular weight fraction) which was activated by ChlA1 only when the nit-1 precursor (low molecular weight fraction) was added back. Thus it is possible to differentiate between nit-1 nitrate reductase reconstitution which occurs as a result of the addition of active molybdopterin and that which results from addition of a source of converting enzyme which activates the nit-1 precursor by the fact that the former requires only the high molecular weight fraction of the nit-1 extract while the latter requires both high and low molecular weight fractions. Recently we have shown that the nit-1 assay can be applied as a sensitive measure of active molybdopterin in fibroblast extracts (13); in such studies it was prudent to use extracts of nit-1 from which all low molecular weight precursors had been removed.

Neither the low molecular weight molybdopterin precursor which accumulates in nit-1 nor the converting enzyme which is present in ChlAl has been fully characterized, although studies to this end are currently in progress. Nevertheless, enough information is already available to allow us to ask whether these late steps in the pathway of cofactor biosynthesis/activation observed in microorganisms are present in humans as well. That is, is the diffusible precursor that accumulates in group B patients related to the molybdopterin precursor in Neurospora nit-1? And, is there an activity in fibroblasts from group A patients that is equivalent to the converting enzyme found in E. coli ChlA1?

Early experiments were directed at the first question. Conditioned medium from group B cells was incubated with ChlAl extracts and then added to extracts of nit- 1 (high molecular weight fraction) and assayed for nitrate reductase reconstitution. No activity was observed, but from the negative result it was not possible to conclude whether the group B precursor differs from the nit-1 precursor and thus was not recognized and activated by $C h l A l$ converting factor or whether levels of precursor were merely too low to detect.

Table IV. Demonstration of Converting Enzyme Activity in Extracts of Fibroblasts from Group A Molybdenum Cofactordeficient Patients by In Vitro Reconstitution of Nitrate Reductase Activity in Neurospora crassa nit-1

\begin{tabular}{cccc}
\hline $\begin{array}{c}\text { Patient } \\
\text { cell line }\end{array}$ & $\begin{array}{c}\text { Complete } \\
\text { nit-1 extract }\end{array}$ & $\begin{array}{c}\text { High molecular } \\
\text { weight fraction }\end{array}$ & $\begin{array}{c}\text { High + low molecular } \\
\text { weight fraction }\end{array}$ \\
\hline A1 & 0.282 & 0.013 & 0.061 \\
A2 & 0.297 & 0.029 & 0.097 \\
A3 & 0.321 & 0.013 & 0.123 \\
B1 & 0.001 & 0.009 & 0.014 \\
\hline
\end{tabular}

Fibroblast extracts were incubated at $4^{\circ} \mathrm{C}$ overnight with complete unfractionated extracts of Neurospora nit-1 to test for the presence of a converting enzyme activity in the fibroblasts which could activate a molybdopterin precursor in the nit-1 extract and allow reconstitution of the Neurospora apo nitrate reductase. The nitrate reductase that was reconstituted was then allowed to react with substrates (nitrate and NADPH) as described in Methods and nitrite formed was quantitated by a colorimetric procedure. Incubations of fibroblast extracts with the isolated high molecular weight fraction of a nit-1 extract (containing apo nitrate reductase but no precursor) and with recombined high and low molecular weight fractions were carried out to determine whether reconstitution was dependent on the presence of the molybdopterin precursor present in the low molecular weight fraction of the nit-1 extract.

* Activity is expressed as absorbance at $540 \mathrm{~nm}$. 
A more fruitful experimental approach was then employed which demonstrated that group A cells contain a converting enzyme which can activate the nit-1 precursor. As shown in Table IV, extracts of fibroblasts from three group A patients were able to reconstitute nitrate reductase activity when incubated with crude, unfractionated extracts of Neurospora nit-1 while an extract of cells from a group B patient failed to produce any active nitrate reductase. The factor in the group A cells responsible for the reconstitution of nitrate reductase was identified as a converting enzyme rather than active molybdopterin (which must be absent in fibroblasts from molybdenum cofactor-deficient patients) by the observations that very little reconstitution occurred in the absence of the nit-1 low molecular weight precursor fraction and that considerable stimulation of reconstitution was observed when the nit-1 low molecular weight fraction was added back. The successful activation of nitrate reductase using group A converting enzyme and nit-1 precursors and the failure of the converse experiment using a potential source of group B precursor and ChlAl converting factor may be attributable to the catalytic nature of the converting enzyme. Very low levels of enzyme when incubated with an excess of substrate can produce significant levels of active molybdopterin while high levels of enzyme and limiting precursor can at most make molybdopterin at a level equal to that of the precursor itself.

The presence of a converting enzyme in fibroblasts from group A patients that can activate the molybdopterin precursor in nit-1 implied that the intermediate which accumulates in fibroblasts is very closely related to that in Neurospora. Confirmation, however, required some way to analyze the precursors themselves. Published work (10) directed at characterizing the molybdopterin precursor in Neurospora nit-1 suggested that an unusual fluorescent pterin species that could be isolated after acidic iodine oxidation of nit-1 extracts might be an inactive oxidized degradation product of the molybdopterin precursor. More recently, we have shown this to be true by the demonstration that the purified active precursor is oxidized to this same fluorescent species (termed compound Z; Johnson et al., manuscript in preparation). Thus, an attempt was made to show the presence of compound $\mathrm{Z}$ in samples from group B patients. Neither conditioned medium nor fibroblasts from group B patients, when treated with acidic iodine, yielded significant levels of compound $\mathrm{Z}$. However, as shown in Fig. 3, a urine sample from patient $B 1$ did indeed contain compound $\mathrm{Z}$. The peak of material eluting at the same position as authentic compound $\mathrm{Z}$, detected by its absorption at $300 \mathrm{~nm}$, was fluorescent and, as shown in Fig. 3, had an absorption spectrum essentially identical to that of the standard material. Significantly, no peak corresponding to compound Z was identified in chromatograms of urine from patient $A l$ or from a control individual. A second aliquot of the same urine sample from patient $B 1$ was processed in the same manner but with the iodine oxidation step omitted. The yield of compound $\mathrm{Z}$ was identical suggesting that conversion of active precursor to compound $\mathrm{Z}$ occurred either before excretion or in the aged sample which had been stored for $5 \mathrm{yr}$ and subjected to many freeze-thaw cycles. A stored sample of urine from patient B2 yielded the same results: a level of compound $\mathrm{Z}$ comparable to that in the B1 sample which did not vary with the inclusion or omission of the iodine oxidation step. Fresh urine samples from patients B1 and B2 were not available for study; however, a fresh sample from patient B3 was obtained
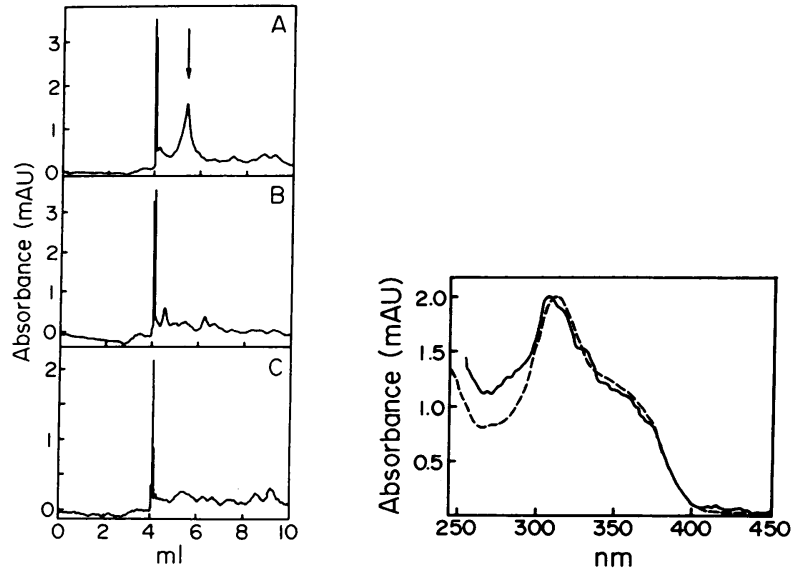

Figure 3. (Left) HPLC elution profiles of urine samples from patients $(A) \mathrm{B} 1,(B) \mathrm{A} 1$, and $(C)$ a control individual. Samples were prepared as described in Methods using in each case $10 \mathrm{ml}$ of urine which contained $(A) 3.5,(B) 5.4$, or $(C) 5.3 \mathrm{mg}$ creatinine. In each case, chromatograms were obtained from $500 \mu$ l of fraction 10 eluted from QAE Sephadex with $0.01 \mathrm{M} \mathrm{HCl}$. The mobile phase was $5 \%$ methanol acidified to $\mathrm{pH} 2$ with $\mathrm{HCl}$ at a flow rate of $1 \mathrm{ml} / \mathrm{min}$. Absorbance was monitored at $300 \mathrm{~nm}$. The arrow in $A$ indicates the elution position of authentic compound Z. (Right) Absorption spectra of compound $\mathrm{Z}$ isolated from urine from patient B1 (-) and of the standard compound (---). Spectra were acquired by on-line diode array detection of HPLC eluants in 5\% methanol acidified to $\mathrm{pH} 2$ with $\mathrm{HCl}$.

and assayed for compound $\mathrm{Z}$. Levels of compound $\mathrm{Z}$ were very low (15\% of that seen in B1) in the sample analyzed without iodine oxidation, but equivalent to $\mathrm{B} 1$ after iodine oxidation.

The iodine-dependent appearance of compound $\mathrm{Z}$ in the sample from patient $B 3$ suggested that it might be possible to detect the presence of the parent functional molybdopterin precursor in a sample which had not been iodine-oxidized. As shown in Table V, incubation of an aliquot of B3 urine with an extract of $C h l A l$ as a source of converting enzyme and the high molecular weight fraction of a Neurospora nit-1 extract did lead to the reconstitution of high levels of nitrate reductase activity. No reconstitution occurred in the absence of the ChlAl extract. As expected, the control urine sample, which

Table V. Demonstration of Active Molybdopterin Precursor in Urine from a Group B Molybdenum Cofactor-deficient Patient by In Vitro Reconstitution of Nitrate Reductase Activity in Neurospora crassa nit-1

\begin{tabular}{lc}
\hline \multicolumn{1}{c}{ Urine sample } & Nitrate reductase activity* \\
\hline B3 (fresh sample) & 1.512 \\
Conrol (fresh sample) & 0.035 \\
B1 (stored sample) & 0.025 \\
\hline
\end{tabular}

Reaction mixtures containing aliquots of urine from group B molybdenum cofactor-deficient patients or a control individual, an extract of $E$. coli ChLAl to provide a source of converting enzyme, and the high molecular weight fraction of an extract of nit-1 to provide apo nitrate reductase were incubated at $4^{\circ} \mathrm{C}$ for $1 \mathrm{~h}$. The nitrate reductase that was reconstituted was allowed to react with substrates and the nitrite formed was quantitated by a colorimetric procedure. * Activity is expressed as absorbance at $540 \mathrm{~nm}$. 
yielded no compound $\mathrm{Z}$ even with iodine oxidation, and the stored sample of urine from patient B1, which yielded its full complement of compound $\mathrm{Z}$ without iodine oxidation, both were incapable of reconstituting significant levels of nitrate reductase activity. A preliminary investigation of the stability of the precursor activity in the urine sample from patient B3 has revealed that activity was not greatly diminished by a number of freeze-thaw cycles but was totally abolished by iodine oxidation.

\section{Discussion}

The presence of converting enzyme in fibroblasts from group $A$ patients and active precursor and compound $Z$ in urine from group B patients is strong evidence that the late steps in the synthesis of molybdopterin in man and microorganisms are identical. The final steps in the pathway of molybdopterin biosynthesis have been summarized in Fig. 1 .

According to this scheme, the molecular defect in group B patients and in the Neurospora nit-1 mutant may be assigned to a gene which codes for or regulates the expression of converting enzyme. As a consequence of this defect, the molybdopterin precursor, which is the substrate for the converting enzyme, and/or its oxidized product accumulate and can be identified in culture media from group B cells, in Neurospora nit- 1 cells (10) and culture medium (Johnson et al., manuscript in preparation), and in urine samples from group B patients. The absence of detectable levels of compound $\mathrm{Z}$ in control urine samples would suggest that under normal circumstances levels of the molybdopterin precursor are quite low; appearance of precursor in extracellular fluids and culture media may result only when intracellular levels are raised due to absence of functional converting enzyme.

The processing of the molybdopterin precursor to yield molybdopterin is carried out by a converting enzyme in group A fibroblasts and ChlAI cells. These results suggest that the molecular defect in group A patients and in ChlAl is earlier in the biosynthetic pathway (prior to the converting enzyme), but do not establish whether the $C h l A l$ and group A mutations are at the same step or in fact whether all group A patients have the same molecular defect. If any or all of the group A patients lack an enzyme which directly precedes converting enzyme on the biosynthetic pathway, they may accumulate the substrate of that defective enzyme. Analysis of urine samples from group A patients for the presence of unusual pterin species which may be related to molybdopterin and the molybdopterin precursor could prove very useful in future studies of molybdopterin biosynthesis in humans.

The converting enzymes in fibroblasts and ChLAl which are assayed by their activation of the nit-1 molybdopterin precursor would appear to have been designed to carry out the same catalytic reaction. Further studies will be required to determine whether the reaction mechanisms are indeed identical and to ascertain the molecular form and cellular localization of the enzymes in these widely divergent life forms.

From the results presented above, it appears very likely that the diffusible precursor produced by group B cells is identical to the molybdopterin precursor present in Neurospora nit-1. The implications of such a conclusion are far-reaching. The precursor in Neurospora nit-1 and certain other $E$. coli molybdopterin mutants is present in extremely high amounts and it, as well as its oxidized product, compound $\mathrm{Z}$, is amenable to purification and structural characterization (Johnson et al., manuscript in preparation). Such information should prove invaluable in terms of understanding how the labile molybdopterin is synthesized and its fragile side chain components protected prior to activation and may ultimately prove to be of therapeutic value to molybdenum cofactor-deficient patients. If further studies verify that the purified molybdopterin precursor isolated from nit-1 is able to reconstitute sulfite oxidase when added to the culture medium of group A cells, the possibility of employing the precursor species in vivo to correct molybdenum cofactor deficiency may indeed become quite real.

\section{Acknowledgments}

This work was supported by grants DK-35029 and NS-05096 from the National Institutes of Health.

\section{References}

1. Shih, V. E., R. Mandell, and J. L. Johnson. 1984. Complementation in variants of sulfite oxidase deficiency. Pediatr. Res. 18:226A. (Abstr.)

2. Duran, M., F. A. Beemer, C. van der Heiden, J. Korteland, P. K. deBree, M. Brink, and S. K. Wadman. 1978. Combined deficiency of xanthine oxidase and sulphite oxidase: a defect of molybdenum metabolism or transport? J. Inherited Metab. Dis. 1:175-178.

3. Johnson, J. L., W. R. Waud, K. V. Rajagopalan, M. Duran, F. A. Beemer, and S. K. Wadman. 1980. Inborn errors of molybdenum metabolism: combined deficiencies of sulfite oxidase and xanthine dehydrogenase in a patient lacking the molybdenum cofactor. Proc. Natl. Acad. Sci. USA. 77:3715-3719.

4. Wadman, S. K., M. Duran, F. A. Beemer, B. P. Cats, J. L. Johnson, K. V. Rajagopalan, J. M. Saudubray, H. Ogier, C. Charpentier, R. Berger, G. P. A. Smit, J. Wilson, and S. Krywawych. 1983. Absence of hepatic molybdenum cofactor: an inborn error of metabolism leading to a combined deficiency of sulphite oxidase and xanthine dehydrogenase. J. Inherited Metab. Dis. 6(Suppl. 1):78-83.

5. Johnson, J. L., and S. K. Wadman. Molybdenum cofactor deficiency. In Metabolic Basis of Inherited Disease, Sixth Edition. C. R. Scriver, A. L. Beaudet, W. S. Sly, and D. L. Valle, editors. McGraw-Hill Book Co., New York. In press.

6. Ogier, H., S. K. Wadman, J. L. Johnson, J. M. Saudubray, M. Duran, J. Boue, A. Munnich, and C. Charpentier. 1983. Antenatal diagnosis of combined xanthine and sulphite oxidase deficiencies. Lancet. 2:1363-1364.

7. Desjacques, P., P. Baltassat, and J. M. Saudubray. Use of chorionic villi for the antenatal diagnosis of xanthine oxidase and sulphite oxidase combined deficiency. J. Inherited Metab. Dis. In press.

8. Johnson, J. L., B. E. Hainline, K. V. Rajagopalan, and B. H. Arison. 1984. The pterin component of the molybdenum cofactor. Structural characterization of two fluorescent derivatives. J. Biol. Chem. 259:5414-5422.

9. Kramer, S. P., J. L. Johnson, A. A. Ribeiro, D. S. Millington, and K. V. Rajagopalan. 1987. The structure of the molybdenum cofactor. Characterization of di-(carboxamidomethyl)molybdopterin from sulfite oxidase and xanthine oxidase. J. Biol. Chem. 262:16357-16363.

10. Johnson, M. E., and K. V. Rajagopalan. 1987. In vitro system for molybdopterin biosynthesis. J. Bacteriol. 169:110-116.

11. Shih, V. E., I. F. Abroms, J. L. Johnson, M. Carney, R. Mandell, R. M. Robb, J. P. Cloherty, and K. V. Rajagopalan. 1977. Sulfite oxidase deficiency. Biochemical and clinical investigations of a heredi- 
tary metabolic disorder in sulfur metabolism. N. Engl. J. Med. 297:1022-1028.

12. Johnson, J. L., and K. V. Rajagopalan. 1982. Structural and metabolic relationship between the molybdenum cofactor and urothione. Proc. Natl. Acad. Sci. USA. 79:6856-6860.

13. Johnson, J. L., M. M. Wuebbens, R. Mandell, and V. E. Shih. 1988. Molybdenum cofactor deficiency in a patient previously characterized as deficient in sulfite oxidase. Biochem. Med. Metab. Biol. 40:86-93.

14. Ogier, H., J. M. Saudubray, C. Charpentier, A. Munnich, J. L. Perignon, A. Kesseler, and J. Frezal. 1982. Double déficit en sulfite et xanthine oxydase, cause d'encéphalopathie due à une anomalie héréditaire du métabolisme du molybdène. Ann. Med. Interne. 133:594-596.

15. Munnich, A., J. M. Saudubray, C. Charpentier, H. Ogier, F. X. Coude, J. Frezal, L. Yacoub, A. Harbi, and S. Snoussi. 1983. Multiple molybdoenzyme deficiencies due to an inborn error of molybdenum cofactor metabolism: two additional cases in a new family. J. Inherited Metab. Dis. 6(Suppl. 2):95-96.

16. Shih, V. E., R. Mandell, and A. Herzfeld. 1982. Defective ornithine metabolism in cultured skin fibroblasts from patients with the syndrome of hyperornithinemia, hyperammonemia and homocitrullinuria. Clin. Chim. Acta. 118:149-157.

17. Amy, N. K., and K. V. Rajagopalan. 1979. Characterization of molybdenum cofactor from Escherichia coli. J. Bacteriol. 140:114124.

18. Johnson, M. E. and K. V. Rajagopalan. 1987. Involvement of $C h l A, E, M$, and $N$ loci in Escherichia coli molybdopterin biosynthesis. J. Bacteriol. 169:117-125.

19. Hawkes, T. R., and R. C. Bray. 1984. Quantitative transfer of the molybdenum cofactor from xanthine oxidase and from sulphite oxidase to the deficient enzyme of the nit-1 mutant of Neurospora crassa to yield active nitrate reductase. Biochem. J. 219:481-493. 